\title{
First attempt to apply whole-lake food-web manipulation on a large scale in The Netherlands
}

\author{
E. Van Donk, ${ }^{1}$ M. P. Grimm, ${ }^{2}$ R. D. Gulati, ${ }^{3}$ P. G. M. Heuts, ${ }^{1}$ W. A. de Kloet ${ }^{3}$ \& L. van Liere $^{3}$ \\ ${ }^{1}$ Provincial Waterboard of Utrecht, P.O. Box 80300, 3508 TH Utrecht, The Netherlands; Present \\ address: Department of Nature Conservation, Aquatic Ecology Section, Agricultural University, P.O. Box \\ 8080, 6700 DD Wageningen, The Netherlands; ${ }^{2}$ Witteveen \& Bos, Consulting Engineers, P.O. Box 233 , \\ 7400 AE Deventer, The Netherlands, ${ }^{3}$ Limnological Institute, 'Vijverhof' laboratory, Rijksstraatweg 6 , \\ 3631 AC Nieuwersluis, The Netherlands
}

Key words: Biomanipulation, whole-lake experiment, lake restoration, Lake Breukeleveen, planktivore fish, Daphnia, predation

\begin{abstract}
Lake Breukeleveen ( 180 ha, mean depth $1.45 \mathrm{~m}$ ), a compartment of the eutrophic Loosdrecht lakes system, was selected to study the effects of whole-lake foodweb manipulation on a large scale. In Lake Loosdrecht (dominated by filamentous cyanobacteria), due to water management measures taken from 1970-1984 (sewerage systems, dephosphorization) the external $\mathrm{P}$ load has been reduced from $1.2 \mathrm{~g} \mathrm{~m}^{-2} \mathrm{y}^{-1}$ to $0.35 \mathrm{~g} \mathrm{~m}^{-2} \mathrm{y}^{-1}$. The water transparency (Secchi-depth ca. $30 \mathrm{~cm}$ ), however, has not improved. The aim of the food-web manipulation in Lake Breukeleveen was not only to improve the light climate of the lake, but also to study if the successfull effects observed in small lakes (a few ha) can be upscaled. In March 1989 the standing crop of planktivorous and bentivorous fish populations was reduced by intensive fishery, from ca. $150 \mathrm{~kg} \mathrm{ha}^{-1}$ to $c a .57 \mathrm{~kg} \mathrm{ha}^{-1}$. The lake was made unaccessible to fish migrating from the other lakes and it was stocked with large-sized daphnids and $0^{+}$pike. However, water transparency did not increase in the following summer and autumn 1989, which is in contrast with great improvement in the light conditions previously observed in smaller lakes. The main explanations for the negative outcome in Lake Breukeleveen are: 1) the rapid increase of the planktivorous fish biomass and carnivorous cladocerans, predating on the zooplankton community; 2) suppression of the large daphnids by the high concentrations of filamentous cyanobacteria; 3 ) high turbidity of the lake due to resuspension of bottom material induced by wind, unlike in smaller lakes, and thus inability of submerged macrophytes to develop and to stabilize the ecosystem.
\end{abstract}

\section{Introduction}

After the successful restoration of the small, eutrophic Lake Zwemlust by food-web manipulation (Van Donk et al., 1989, 1990), the Provincial Waterboard of Utrecht (The Netherlands) decided to attempt analogous restoration mea- sures in lake Breukeleveen, a hundred times larger lake. Lake Breukeleveen, a compartment of the Loosdrecht lakes system, became highly eutrophic by external loadings of phosphorus and nitrogen. This led to serious water quality problems, especially the high densities of cyanobacteria (De Kloet et al., 1984). These changes 
were accompanied by a decline in submerged vegetation (Best et al., 1984). Water management measures were taken from 1970-1984 (sewerage systems, dephosphorization) to reduce the external total-P load to these lakes from $1.2 \mathrm{~g} \mathrm{P} \mathrm{m}^{-2}$ $y$ ' to $0.35 \mathrm{~g} \mathrm{P} \mathrm{m}^{2} \mathrm{y}$ ' (Van Liere et al, in press). Although summer averages of both total-P and chlorophyll- $a$ of the Loodrechts lakes system markedly decreased from 1980-1984 (Van Liere et al., 1990), this decrease did not proceed with the same rate in the years after 1984.

The aim of applying food-web manipulation measures to Lake Breukeleveen was not only to accelerate the restoration of the lake but also to study in how far effects found in a small-scale experiment, like Lake Zwemlust (Van Donk et al., $1989,1990)$, can be observed in larger lakes. The other compartments of Lake Loosdrecht may serve first as references and are planned to be treated later, if the results of measures on Lake Breukeleveen project are promising. The power of this approach lies in its ability to confirm that results observed in response to the initial treatment are reproducible in a second compartment. If successfull in the different lake parts, despite the prevailing limnological differences between these parts, it can add to our confidence in the manipulation approach (Frost et al., 1988).

\section{Lake description and background limnology}

Lake Breukeleveen is one of the compartments of the eutrophic Loosdrecht lakes system (Fig. 1), which has been formed by excavation of peat during the 17th and 18th century (Kal et al., 1984). Lake Breukeleveen is shallow (mean depth $1.45 \mathrm{~m}$ ) with a surface area of $1.8 \mathrm{~km}^{2}$. The seepage losses of water from the lake to a lowlying polder are replenished by inflow of water from Lake Loosdrecht, through two small waterways (Fig. 1). The water from Lake Loosdrecht is rich in $\mathrm{P}$ (summer average of total-P was $c a$. $100 \mu \mathrm{g} \mathrm{I}^{-1}$; Table 1); also summer average chlorophyll- $a$ exceeds $100 \mu \mathrm{g} \mathrm{I}^{-1}$. Eutrophication led to increase in turbidity which in turn led to the disappearance of submerged macrophytes and

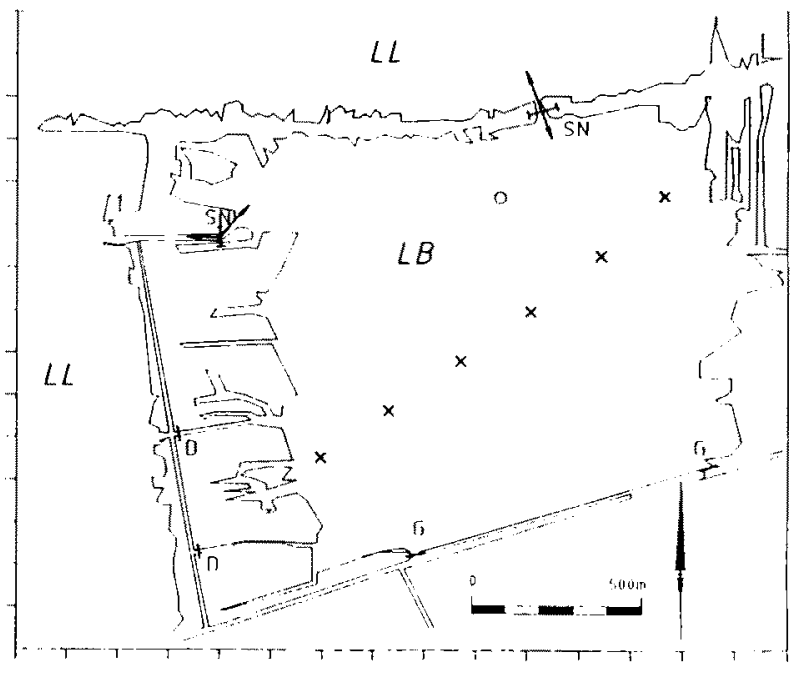

Fig. 1. Schematic map of Lake Breukeleveen (LB) with sampling stations ( $O=$ WQL ( = Water Quality Loosdrecht) station; $x=$ PWB ( = Provincial Water Board station) and fish barriers ( $S N=$ sinknet; $G=$ gate; $D=$ dam) $L L=$ Lake Loosdrecht.

accumulation of debris at the lake bottom. Lake Breukeleveen has the form of a square, the SWdiagonal representing also the prevailing wind direction in this area; absence of islands accentuates the windfetch effect, this contributing to resuspension of bottom-material and high degree of turbidity (Gons, 1987).

The phytoplankton was dominated by filamentous cyanobacteria, namely Oscillatoria redekei and O. limnetica (De Kloet et al., 1984) and the prochlorophyte Prochlorothrix hollandica (Burger-Wiersma et al., 1986). The zooplankton comprised predominantly small-sized cladocerans (Bosmina spp., Chydorus sphaericus, Daphnia cucullata), while large-sized crustacean zooplankton was conspicuous by its absence (Gulati, 1990). Bream (Abramis brama) comprised $90 \%$ of lake's total fish biomass. The average growth of the fish, however, and its condition, especially the fish $>30 \mathrm{~cm}$, were low (Van Densen et al., 1986). Pike (Esox lucius) and pikeperch (Stizostedion lucioperca) were the main piscivore fish species. The total fish biomass was estimated at $c a .150 \mathrm{~kg} \mathrm{ha}^{-1}$. 


\section{Methods}

\section{Foodweb manipulation measures}

The planktivorous and benthivorous fish populations were reduced in March 1989. Target standing crop levels after the reduction were set arbitrarily at 20-50 $\mathrm{kg} \mathrm{ha}^{-1}$ for $1^{+}$and older fish, and $10-15 \mathrm{~kg} \mathrm{ha}^{-1}$ for $0^{+}$fish. The main gear used was a beach seine (length $550 \mathrm{~m}$; height $8 \mathrm{~m}$; stretched mesh in wings $40 \mathrm{~mm}$ and in pouch $32 \mathrm{~mm}$; length of hauling ropes $600 \mathrm{~m}$ ). The pouch of the seine with two adjacent wing sections of $25 \mathrm{~m}$ could be replaced by a finemeshed one $(10 \mathrm{~mm})$. The section of the lake fished was blocked off from the remaining lake part by blocknets (stretched mesh $14 \mathrm{~mm}$; total length $3 \mathrm{~km}$ ). Thus, section by section fishing and blocking, led the fish to concentrate in the unfished part, such that the whole lake could be seined in 5 days. This operation was repeated twice, thereafter, the fish caught were stored first and later transported in bins. The average weight per transport was recorded. The length of all fish in one out of every ten bins was measured to the nearest $0.5 \mathrm{~mm}$ and fish were weighed to the nearest two grams. During the second thinning fishery fish were marked at random by partial removal of the pectoral fin. The mark-recapture ratio was calculated using the data from the third seine fishery and of a last sampling by trawl, since the mark-recapture data of the seine fishery may be biased by gear avoidance (Beukema \& de Vos, 1974; Buck \& Thoits, 1965). About $93 \mathrm{~kg} \mathrm{ha}^{-1}$ of the original standing crop of $c a .150 \mathrm{~kg} \mathrm{ha}^{-1}$, were removed; bream comprised the bulk ( $c a$. $89 \mathrm{~kg} \mathrm{ha}^{-1}$ ) of the total fish removed.

Sink nets were installed in the two waterways which connect Lake Breukeleveen with Lake Loosdrecht, to prevent fish immigration (Fig. 1). Infra-red sensors automatically lowered the nets to let boats pass. In the three remaining small connections with other waterways, dams and gates were built. The lake was restocked with $0^{+}$ pike (400 ind. ha ' $; c a .2-3 \mathrm{~cm}$ ) and large-sized daphnids (ca. 12 ind. $\mathrm{m}^{-3} ;$ D. hyalina and D. pulex).

\section{Water chemistry and biology}

Before and after the manipulation, the lake was sampled 4-weekly at one station (WQL station in Fig. 1). The techniques of sampling and monitoring lake's limnology are outlined in different publications in Loogman \& Van Liere (1986). In 1989 , besides the 4-weekly monitoring, the lake was also sampled fortnightly at six stations (PWB stations in Fig. 1) to study spatial heterogeneity; for procedures used see Van Donk et al. (1989). The spatial samples are pooled for description of results in this paper.

The development of the fish stock was monitored during the growing season. In June and July $0^{+}$fish were sampled by a small trawl with a fixed frame $(0.8 \times 2.2 \mathrm{~m}$; stretched mesh size $4 \mathrm{~mm})$. Per sampling 20 hauls of $c a .3$ min each were made. In mid July and September the fish population was sampled using the large trawl mentioned earlier. The efficiency of the small trawl was calibrated using the data of a simultaneous sampling effort with the large trawl ( 5 hauls of $10 \mathrm{~min}$ ). The gear efficiency of the large trawl was calculated using the data from the sampling in January and the population estimates based on the results of the reduction fishery in March was about $90 \%$ for fish up to $26 \mathrm{~cm}$, and about $70 \%$ for larger individuals. The efficiency of the small trawl for fry was $45 \%$.

Nutrient enrichment experiments (bioassays), zooplankton grazing $\left({ }^{14} \mathrm{C}\right.$-tracer technique) and primary production rates were measured to assess the factors limiting the growth of the phytoplankton and to quantify the role of zooplankton grazing. These methods are outlined in Van Donk et al. (1990).

\section{Results}

Nutrients, phytoplankton and bioassays

The mean concentrations of parameters during the growth season (April-September), indicating the trophic state of Lake Loosdrecht and Lake Breukeleveen (Table 1), do not indicate any sig- 
Table 1. Mean concentrations of parameters during the growth season (April-September), indicating the trophic state of Lake Breukeleveen and Lake Loosdrecht.

\begin{tabular}{|c|c|c|c|c|c|c|}
\hline \multirow[t]{2}{*}{ Year } & \multicolumn{3}{|c|}{ Lake Breukeleveen } & \multicolumn{3}{|c|}{ Lake Loosdrecht } \\
\hline & $\begin{array}{l}\text { Total-P } \\
\left(\left.\mu \mathrm{g}\right|^{-1}\right)\end{array}$ & $\begin{array}{l}\text { Chlorophyll-a } \\
\left(\mu \mathrm{gl}^{-1}\right)\end{array}$ & $\begin{array}{l}\text { Suspended } \\
\text { matter } \\
\left(\text { mg DW }^{-1}\right)\end{array}$ & $\begin{array}{l}\text { Total-P } \\
\left(\mathrm{mg} \mathrm{l}^{-1}\right)\end{array}$ & $\begin{array}{l}\text { Chlorophyll-a } \\
\left(\mu \mathrm{gl}^{-1}\right)\end{array}$ & $\begin{array}{l}\text { Suspended } \\
\text { matter } \\
\left(\mathrm{mg} \mathrm{DW} 1^{-1}\right)\end{array}$ \\
\hline 1985 & 110 & 112 & 37 & 113 & 125 & 31 \\
\hline 1986 & 105 & 126 & 44 & 111 & 155 & 42 \\
\hline 1987 & 93 & 127 & 37 & 85 & 120 & 30 \\
\hline 1988 & 107 & 113 & 37 & 96 & 116 & 33 \\
\hline 1989 & 106 & 91 & 35 & 102 & 119 & 35 \\
\hline
\end{tabular}

nificant changes in Lake Breukeleveen in 1989; this holds true also for Lake Loosdrecht in general. However in Lake Breukeleveen the chlorophyll-a concentration in 1989 was lower than in Lake Loosdrecht. Nevertheless, it is premature to say that this difference is due to the biomanipulation measure, since such differences have been also observed earlier in the Loosdrecht lakes system (Van Liere et al., in press). Secchi disc transparency ranged between 30 and $40 \mathrm{~cm}$, indicating no change. Also phytoplankton composition and abundance in 1989 did not change significantly, compared with preceding years in the lake itself as well as in Lake Loosdrecht. In the summer of 1989 Oscillatoria species (O. redekei and $O$. limnetica) and $P$. hollandica were still predominant with a mean concentration of $2.310^{5}$ filaments $\mathrm{ml}^{-1}$ in Lake Breukeleveen and $2.410^{5}$ fil. $\mathrm{ml}^{-1}$ in Lake Loosdrecht (Boesewinkel-de Bruijn, pers. comm.); this is $2-3$ fold higher than at the start of the experiment in March 1989.
The outcome of the bioassays before manipulation (July 1988) and after manipulation (July 1989) did not significantly differ (Table 2 ). The net growth rate of the phytoplankton community was very low in all combinations $\left(\mu<0.05 \mathrm{~d}^{-1}\right)$ and there were no significant differences between the bioassays performed on one date. According to the assays the phytoplankton in Lake Breukeleveen was not limited by nutrients before or after the food-web manipulation. Mortality induced by zooplankton grazing did not seem to be of any importance. Light was the most probable growth controlling factor of the phytoplankton during the summer, self-shading being high.

\section{Zooplankton and crustacean grazing}

The crustacean zooplankton in 1989 , like in the preceding years (Gulati, 1990), i.e. period before

Table 2. The mean net growth rates $\left(\bar{\mu}\right.$ day $\left.{ }^{-1}\right)$ of the phytoplankton community of Lake Breukeleveen in the bioassays for the different combinations. Blank, zooplankton removed [B]; zooplankton not removed, no nutrient additions [+Zoopl]; $\left(\mathrm{NO}_{3}\right)$ added, $0.56 \mathrm{mg} \mathrm{N}^{-1}$ and $\left(\mathrm{NH}_{4}\right), 0.30 \mathrm{mg} \mathrm{N}^{-1}[+\mathrm{N}] ;\left(\mathrm{PO}_{4}\right)$ added, $0.32 \mathrm{mg} \mathrm{Pl}^{-1}[+\mathrm{P}]$; addition of complete freshwater medium [Total]. The $95 \%$ confidence intervals are given in parentheses.

\begin{tabular}{|c|c|c|c|c|c|c|}
\hline \multirow[t]{2}{*}{ Date } & \multicolumn{2}{|r|}{$\bar{\mu} \mathrm{da}$} & \multirow[b]{2}{*}{$+N$} & \multirow[b]{2}{*}{$+\mathbf{P}$} & \multirow[b]{2}{*}{+ Zoopl } & \multirow[b]{2}{*}{ Total } \\
\hline & $\begin{array}{l}\text { Watertemp. } \\
\left({ }^{\circ} \mathrm{C}\right)\end{array}$ & B & & & & \\
\hline $1988-07-12$ & 18 & $0.01(0.02)$ & $0.02(0.01)$ & $0.03(0.02)$ & $0.02(0.02)$ & $0.04(0.03)$ \\
\hline $1989-07-28$ & 22 & $0.02(0.03)$ & $0.03(0.02)$ & $0.02(0.03)$ & $0.05(0.03)$ & $0.05(0.01)$ \\
\hline
\end{tabular}




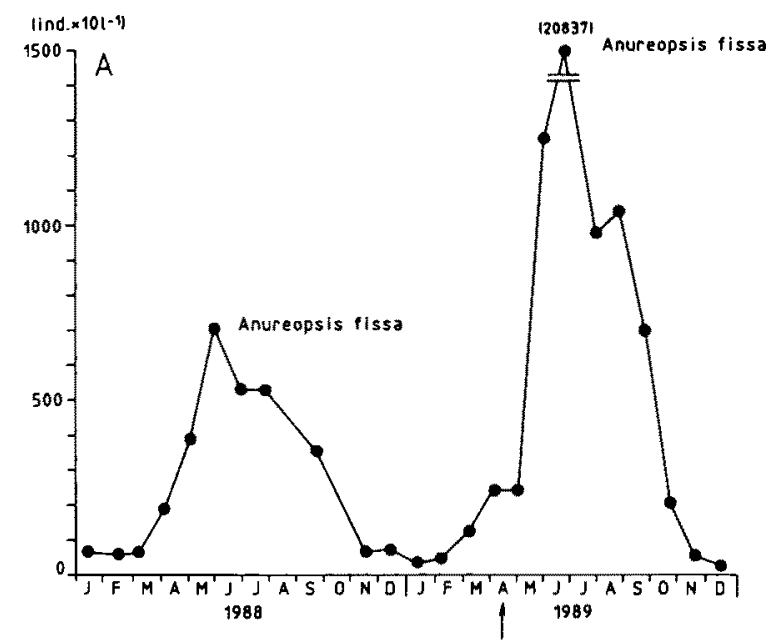

biomanipulation, was characterized by the presence of: 1) cyclopoid copepods and their nauplii, which fluctuated around 500 ind $1^{-1}$ during spring and summer, and 2) cladocerans (mainly Bosmina longirostris and B. coregoni and Chydorus sphaericus), which dominated in May with a peak of 1500 ind. $1^{-1}$ (Fig. 2). Daphnia cucullata, which fluctuated between 10 and 20 ind $1^{-1}$ in the initial few weeks after biomanipulation, increased markedly up to mid June (Fig. 3), declined subsequently and remained sparse during rest of the year. The Daphnia maximum of 270 ind. $1^{-1}$ this year is the highest recorded for daphnids since 1981, from which year onwards the lake has been regularly monitored (unpublished data of R. D. Gulati, see also Gulati, 1990). The stocked, largesized daphnids were only occasionally encountered in the samples $\left(<5\right.$ ind. $\left.1^{-1}\right)$. After fish removal, Leptodora kindtii a carnivorous cladoceran increased, with $c a .10$ ind. $1^{-1}$ at the end of May. Rotifers, like in the years 1981-88, formed the dominant micro-zooplankton in the open water. Anuraeopsis fissa, the smallest of all rotifers in Lake Loosdrecht, including Lake Breukeleveen, contributed ca. $90 \%$ of total rotifer density on 28 June and about two-thirds of the annual average total rotifer density $\left(5383 \pm 6334\right.$ ind. $\left.1^{-1}\right)$.

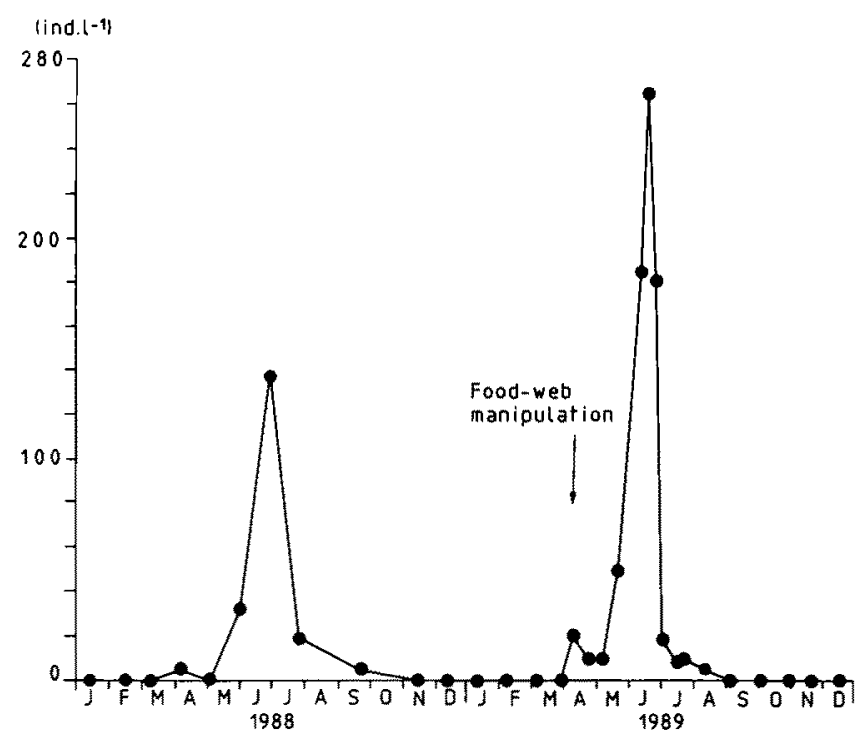

Fig. 3. The abundance of the cladoceran Daphnia cucullata in Lake Breukeleveen in the year before (1988) and after (1989) the food-web manipulation. 
$B$. coregoni, the only cladoceran which was encountered in all samples from 5 April to 13 December 1989, had the highest fecundity in spring. The percentage of adult females decreased from $>90 \%$ in April-May to zero $\%$ in August. A similar pattern was observed for the egg-bearing population, i.e. a fecundity minimum in mid summer when Bosmina population of 50 ind. 1 I was comprised virtually of juveniles only, which had mean annual size minimum of $0.29 \mathrm{~mm}$; the mean population length in summer was only onehalf of the mean length in April. Subsequently in late summer/autumn, even though the mean clutch size of 1.3 eggs per egg-bearing female was similar to the size in spring, the minimum, maximum and mean lengths were all relatively lower, i.e. the animals appeared to mature at a shorter length than in spring. For D. cucullata the percentage of adult females in the total population was much lower than for Bosmina sp., decreasing from $60 \%$ at the end of May to $42 \%$ at the end of June. Also the daphnid clutch size decreased in mid summer, like in Bosmina sp. The decrease, however, coincided with a three-fold increase in population density (Fig. 2). In the end of July the daphnid population decreased to 10 ind. $1^{-1}$ and the clutch size decreased further, despite no observable changes in mean population length or adult length compared with May.

The mean daily grazing rate by curstacean zooplankton in Lake Breukeleveen of $13.6 \pm 16.2 \% \mathrm{~d}^{-1}$ in 1989 (Table 3) was somewhat higher than rates measured in this lake, as well as Lake Loosdrecht, in the years 1982-1984 for which years grazing data are available (Gulati, 1984). However, zooplankton grazing was important only in spring and early summer ( 5 April-28 June) when the grazing rates based on seston food fraction $<33 \mu \mathrm{m}$ (see Table 3 ) varied between 10 and $48 \% \mathrm{~d}^{-1}$. Especially in May the food daily ingested by zooplankton was high; it equalled between one-quarter and one-half of the seston $(<33 \mu \mathrm{m})$ standing crop. In this period of relatively high grazing rates the densities of filterfeeding crustaceans, particularly $B$. coregoni, Chydorus sphaericus and $D$. cucullata, were also high. In late May all these species, but especially the Daphnia sp., mainly contributed to the annual grazing maximum of $48 \% \mathrm{~d}^{-1}$. By the end of June, the zooplankton grazing pressure had decreased to about one-fourth the level in late May i.e. to about $13 \% \mathrm{~d}^{-1}$, even though the filterfeeders densities had only halved between late May and late June. This apparent discrepancy between the decrease in grazing rates and the grazers' density is related to a decrease in average size per individual of the main grazer species, viz. $D$. cucullata and B. coregoni, as well as a decrease of $\mathrm{ca} .25 \%$ in zooplankton community biomass in June compared with its biomass early in May.

Table 3. Primary production, grazing and assimilation rates of the phytoplankton and crustacean zooplankton community and other relevant data of Lake Breukeleveen in 1989. $\mathrm{S}$, seston food $\left(\mathrm{mg} \mathrm{Cl}^{-1}\right)$; $\mathrm{Z}$, zooplankton biomass (mg Cl ${ }^{-1}$ ); PP, primary production (mg Cl $\mathrm{Cl}^{-1} \mathrm{~d}^{-1}$ ); SPP. specific primary production ( $\left.\mathrm{mg} \mathrm{C} \mathrm{mg} \mathrm{Chl}^{-1} \mathrm{~d}^{-1}\right)$; $\mathrm{G}$, grazing (\% $\mathrm{d}^{-1}$ ); SCR, specific clearance rate $\left(1 \mathrm{mg} \mathrm{C}^{-1} \mathrm{~d}^{-1}\right) ; \mathrm{A}$, assimilation ( $\left.\mathrm{mg} \mathrm{Cl} \mathrm{l}^{-1} \mathrm{~d}^{-1}\right)$; $\mathrm{C}$, consumption ( $\mathrm{mg} \mathrm{Cl}^{-1} \mathrm{~d}^{-1}$ ) and SDA, specific daily assimilation $\left(A, Z\right.$ in $\left.{ }^{\circ}\right) .(-$ experiment failed).

\begin{tabular}{|c|c|c|c|c|c|c|c|c|c|c|c|}
\hline \multirow{2}{*}{$\frac{\text { Date }}{89-05-04}$} & \multirow{2}{*}{$\frac{\mathrm{T}^{\circ} \mathrm{C}}{5.8}$} & \multicolumn{2}{|c|}{$\mathrm{S}(<30 \mu / 30-150 \mu)$} & \multirow{2}{*}{$\frac{Z(>150 \mu)}{0.68}$} & \multirow{2}{*}{$\begin{array}{l}P P \\
0.32\end{array}$} & \multirow{2}{*}{$\begin{array}{r}\text { SPP } \\
3.9\end{array}$} & \multirow{2}{*}{$\frac{G}{9.9}$} & \multirow{2}{*}{$\frac{\text { SCR }}{0.15}$} & \multirow{2}{*}{$\frac{\mathrm{C}}{1.14}$} & \multirow{2}{*}{$\begin{array}{l}\text { A } \\
0.48\end{array}$} & \multirow{2}{*}{$\frac{\text { SDA }}{71}$} \\
\hline & & 11.5 & 0.6 & & & & & & & & \\
\hline $03-05$ & 15.2 & 8.1 & 1.8 & 0.59 & 0.48 & 8.1 & 26.7 & 0.45 & 2.16 & 0.31 & 52 \\
\hline $30-05$ & 16.4 & 8.1 & 2.7 & 1.32 & 0.95 & 8.8 & 47.9 & 0.36 & 3.87 & 1.24 & 94 \\
\hline $28-06$ & 19.3 & 9.0 & 1.0 & 0.41 & 1.01 & 11.9 & 12.8 & 0.31 & 1.16 & 0.42 & 102 \\
\hline $26-07$ & 21.6 & 11.7 & 2.0 & 0.33 & 0.55 & 6.2 & 2.1 & 0.06 & 0.25 & 0.20 & 61 \\
\hline $23-08$ & 21.0 & 9.7 & 3.1 & 0.15 & 0.59 & 6.2 & - & - & - & - & - \\
\hline $20-09$ & 17.8 & 10.3 & - & 0.14 & 0.54 & 4.5 & - & - & - & - & - \\
\hline $18-10$ & 11.5 & 8.0 & 0.9 & 0.14 & 0.30 & 4.1 & 3.0 & 0.21 & 0.24 & 0.07 & 52 \\
\hline $15-11$ & 6.5 & 7.9 & 1.3 & 0.23 & 0.26 & 3.0 & 4.7 & 0.20 & 0.37 & 0.18 & 77 \\
\hline $13-12$ & 2.4 & 5.1 & 0.8 & 0.16 & 0.07 & 1.5 & 1.1 & 0.07 & 0.06 & 0.02 & 11 \\
\hline
\end{tabular}


Mean specific clearance rate of $0.23 \pm 0.14 \mathrm{I} \mathrm{d}^{-1}$ $\mathrm{mg}^{-1}$ zooplankton carbon during 1989 is also comparable with the mean rates in the years 1982-1984 (Gulati, 1984) in Lake Loosdrecht in general. Similarly assimilation efficiencies of the food ingested corresponded to the earlier data on this lake. In mid summer (July-August) an increase in seston, especially of the size fraction $33-150 \mu \mathrm{m}$, was accompanied by a decrease in zooplankton biomass, filter-feeders densities and grazing pressure to low levels (Table 3 ).

\section{Fish}

The total fish biomass was reduced in March 1989 to about one-third after the thinning operation, i.e. from 150 to $57 \mathrm{~kg} \mathrm{ha}^{-1}$. The biomass estimates of the fish removed per species and per length class, and of the fish remaining in the lake, as well as total fish before the thinning operations, are presented in Table 4. The results of the monitoring fishery with the large trawl after the manipulation are presented in Table 5; for estimates of $0^{+}$fish see Table 6. Within six months after manipulation the fish biomass increased again to values as high as before the measures (Table 5). Assuming that no mortality occurred individual growth rate explained an increase of $23 \mathrm{~kg}$ in bream biomass and of $3 \mathrm{~kg}$ roach biomass per ha. The observed increases, however, are about 4 and 5 times higher ( $c a .86$ and $c a .17 \mathrm{~kg} \mathrm{ha}^{-1}$ ) respectively, indicating immigration, especially bream of $15-25 \mathrm{~cm}$ from the other compartments of the lake. The numbers of $0^{+}$cyprinids remained fairly stable from June to September, those of the pikeperch (Stizostedion lucioperca), perch (Perca fluviatilis), ruffe (Gymno-

Table 4. Estimates of fish biomass $\left(\mathrm{kg} \mathrm{ha}^{-1}\right.$ ) in Lake Breukeleveen; I original population; II fish removed; and III fish population remaining (dash represents no estimates). Others include Perch, Smelt, Ruffe and Carp.

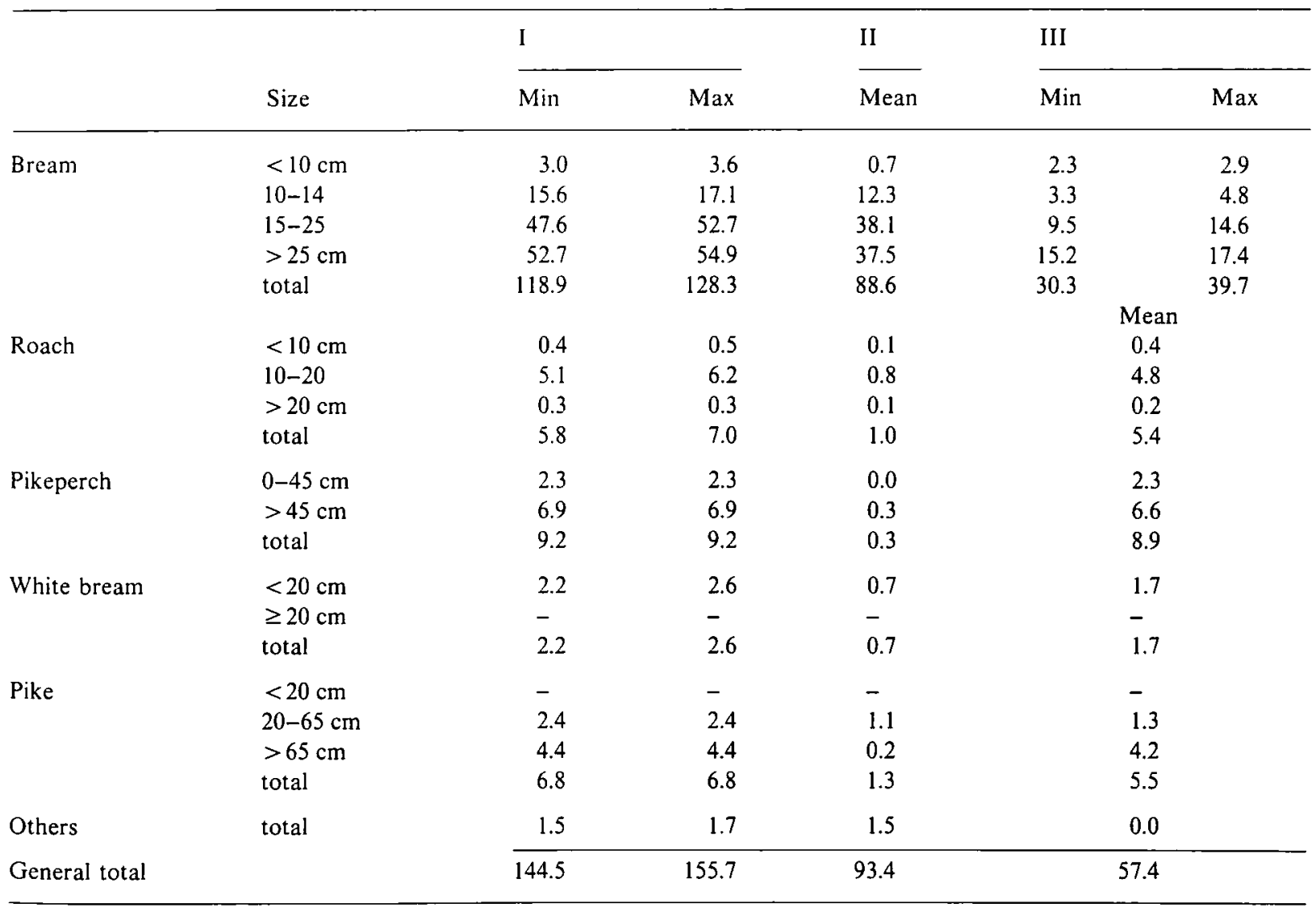


Table 5. Estimates of the fish population ( $\mathrm{kg} \mathrm{ha}^{-1}$ ) in 1989 in Lake Breukeleveen after food-web manipulation, based on the trawl fishery. (dash represents no estimates). Others include Perch, Smelt and Carp.

\begin{tabular}{|c|c|c|c|c|c|}
\hline & & \multicolumn{2}{|l|}{ July } & \multicolumn{2}{|c|}{ September } \\
\hline & & Min & $\operatorname{Max}$ & Min & $\operatorname{Max}$ \\
\hline Bream & $\begin{array}{l}0^{+} \\
<10 \mathrm{~cm} \\
10-14 \\
15-25 \\
>25 \mathrm{~cm} \\
\text { total }\end{array}$ & $\begin{array}{r}7.0 \\
3.5 \\
6.3 \\
23.7 \\
8.5 \\
49.0\end{array}$ & $\begin{array}{r}8.7 \\
4.4 \\
7.9 \\
29.6 \\
11.3 \\
61.9\end{array}$ & $\begin{array}{r}17.4 \\
2.1 \\
9.1 \\
46.4 \\
31.9 \\
106.9\end{array}$ & $\begin{array}{r}21.8 \\
2.7 \\
11.3 \\
58.0 \\
42.5 \\
136.3\end{array}$ \\
\hline Roach & $\begin{array}{l}0^{+} \\
<10 \mathrm{~cm} \\
10-20 \\
>20 \mathrm{~cm} \\
\text { total }\end{array}$ & $\begin{array}{l}4.5 \\
0.8 \\
3.0 \\
- \\
8.3\end{array}$ & $\begin{array}{c}5.6 \\
1.1 \\
3.7 \\
- \\
10.4\end{array}$ & $\begin{array}{c}9,0 \\
1.1 \\
9.8 \\
- \\
19.9\end{array}$ & $\begin{array}{r}11.3 \\
1.3 \\
12.2 \\
- \\
24.8\end{array}$ \\
\hline Pikeperch & $\begin{array}{l}0^{+} \\
0 \pm 45 \mathrm{~cm} \\
>45 \mathrm{~cm} \\
\text { total }\end{array}$ & $\begin{array}{l}0.8 \\
0.7 \\
- \\
1.5\end{array}$ & $\begin{array}{l}1.0 \\
0.9 \\
- \\
1.9\end{array}$ & $\begin{array}{r}0.1 \\
2.1 \\
14.3 \\
16.5\end{array}$ & $\begin{array}{r}0.1 \\
2.6 \\
19.1 \\
21.8\end{array}$ \\
\hline White bream & $\begin{array}{l}0^{+} \\
<20 \mathrm{~cm} \\
\geq 20 \mathrm{~cm} \\
\text { total }\end{array}$ & $\begin{array}{l}- \\
1.0 \\
\overline{1.0}\end{array}$ & $\begin{array}{l}- \\
1.2 \\
- \\
1.2\end{array}$ & $\begin{array}{l}- \\
3.6 \\
0.3 \\
3.9\end{array}$ & $\begin{array}{l}- \\
4.5 \\
0.4 \\
4.9\end{array}$ \\
\hline Pike & $\begin{array}{l}0^{+} \\
<20 \mathrm{~cm} \\
20-65 \mathrm{~cm} \\
>65 \mathrm{~cm} \\
\text { total }\end{array}$ & $\begin{array}{l}- \\
\overline{0} \\
\overline{0.3} \\
0.3\end{array}$ & $\begin{array}{l}- \\
- \\
0.4 \\
- \\
0.4\end{array}$ & $\begin{array}{l}- \\
0.0 \\
1.8 \\
- \\
1.8\end{array}$ & $\begin{array}{l}- \\
0.0 \\
2.4 \\
- \\
2.4\end{array}$ \\
\hline Others & total & 7.7 & 9.9 & 7.7 & 9.5 \\
\hline General Total & & 67.9 & 85.6 & 156.7 & 199.7 \\
\hline
\end{tabular}

cephalus cernua) and smelt (Osmerus eperlanus) declined markedly between June and July (Table 6). The total biomass of the $0^{+}$fish $\left(25-41 \mathrm{~kg} \mathrm{ha}^{-1}\right)$ remained rather constant.

\section{Macrophytes}

In 1989 only a few submerged species were recorded, most possessed floating leaves. Nuphar lutea and Nymphaea alba were quite common in the eastern and western parts of the lake. Nymphoides peltata was found in the southwest and in the northwest corners of the lake and the nymphoid-water-form of Polygonum amphibium on the eastern coast. Also very small patches of Potamogeton lucens and Stratiotes aloides were encountered. Earlier investigations (Leentvaar \& Mörzer Bruijns, 1962) indicate that macrophytic vegetation changed markedly since 1942 , when almost the entire bottom of the lake was covered with characeans. By 1961 the characeans had disappeared and there was an abundant vegetation of Potamogeton lucens, $P$. perfoliates, Nymphaea alba, Ceratophyllum demersum and Hottonia palustris. 
Table 6. The estimated numbers (I) (ind. ha ') and biomasses (II) ( $\mathrm{g} \mathrm{ha}{ }^{-1}$ ) of $0^{+}$fish in Lake Breukeleveen in 1989 after the food-web manipulation. $\mathrm{A}=$ roach, $\mathrm{B}=$ bream, $\mathrm{C}=$ pikeperch, $\mathrm{D}=$ perch, $\mathrm{E}=$ smelt, $\mathrm{F}=$ ruffe.

\begin{tabular}{|c|c|c|c|c|c|c|c|c|}
\hline & & A & B & $\mathrm{C}$ & $\mathrm{D}$ & $\mathrm{E}$ & $F$ & Total \\
\hline \multirow{2}{*}{\multicolumn{2}{|c|}{$\begin{array}{ll}\text { June } & \text { I } \\
& \text { II }\end{array}$}} & 4509 & 10975 & 22789 & 20628 & 10808 & 589 & 70719 \\
\hline & & 1242 & 3184 & 8253 & 14727 & 5424 & 157 & 32988 \\
\hline \multirow{2}{*}{$\begin{array}{ll}\text { July I } \\
\\
\text { I }\end{array}$} & I & 6383 & 10608 & 2092 & 2110 & 6326 & 2581 & 30109 \\
\hline & II & 6288 & 8561 & 1491 & 2400 & 5647 & 3174 & 27561 \\
\hline \multirow{2}{*}{ Sept. I } & & 6672 & 9934 & 120 & 774 & 3838 & 338 & 21678 \\
\hline & II & 10178 & 19612 & 108 & 1182 & 5320 & 548 & 36949 \\
\hline
\end{tabular}

\section{Discussion}

The application of food-web manipulation in Lake Breukeleveen in March 1989 did not improve the underwater light climate in the ensuing summer and autumn periods. This in contrast with the results found for the small lake Zwemlust, in which lake despite the four times higher $\mathrm{N}$ and $\mathrm{P}$ loads, zooplankton grazing increased and controlled the phytoplankton abundance already within two months after fish removal (Van Donk etal., 1989, 1990). In Lake Breukeleveen there was also no change in the mean summer chlorophyll- $a$ concentration ( $c a$. $90 \mu \mathrm{g}^{-1}$ ), whereas in Lake Zwemlust chlorophyll- $a$ concentrations decreased from $250 \mu \mathrm{g}$ $1^{-1}<5 \mu \mathrm{gl}^{-1}$. After the fish removal both lakes were stocked with large-bodied daphnids in such numbers that the starting concentration in the two lakes were comparable ( $c a .0 .012$ ind. $1^{-1}$ ). In Lake $Z$ wemlust these stocked daphnids increased to relatively high concentrations within 10 weeks (D. hyalina ca. 90 ind. $1^{-1}, D$. magna ca. 30 ind. $1^{-1}$ : Gulati, 1989). In Lake Breukeleveen, however, large-bodied daphnids were extremely sparse $\left(<1\right.$ or 2 ind. $\left.1^{-1}\right)$ only occasionally found in the sampels during the whole summer and autumn.

Several possible explanations can be given for this striking difference in the outcome in the two lakes. Low population density of large-bodied zooplankton are frequently attributed to predation by $0^{+}$fish (Gliwicz \& Pijanowska, 1989). In contrast to Lake Zwemlust, in Lake
Breukeleveen the standing crop of planktivorous fish was only partially removed. Moreover, the remaining biomass $\left(c a .57 \mathrm{~kg} \mathrm{ha}^{-1}\right.$ of planktivorous fish, Table 4 ) increased rapidly after the manipulation and reached values as high as before within 6 months ( $c a .150 \mathrm{~kg} \mathrm{ha}^{-1}$, Table 5). In June, i.e. 3 months after the manipulation, the biomass of $0^{+}$fish was estimated at $c a .33 \mathrm{~kg}$ $\mathrm{ha}^{-1}$ (Table 6). So, the continuous absence of larger zooplankton may well have been due to fish predation. The increase of the fish biomass due to immigration of fish from adjacent waters, probably occurred after mid July, when one of the gates stopped functioning, due to vandalism. Hence this immigration is considered to be unimportant in the failure to create a cascading topdown-effect.

The densities of the invertebrate predator Leptodora kindtii of 10 ind. $1^{-1}$ are the higehst so far known for Lake Loosdrecht (see e.g. Gulati, 1990) and were perhaps caused by initial fish reduction followed by mild spring temperatures. So also predation by this carnivorous crustacean may have had impact on the Daphnia population dynamics (Karabin, 1974). Leptodora of 4-5 mm length consume about 10 prey ind. ${ }^{-1}$ day $^{-1}$ at $10^{\circ} \mathrm{C}$ (Mordukhai-Bottovskaya, 1958).

Besides, filtering rates of large-sized cladocerans especially Daphnia spp. may be depressed due to abundance of filamentous cyanobacteria (e.g. Gliwicz, 1977; Edmondson \& Litt, 1982; Richman \& Dodson, 1983). Filaments cause serious disturbance of the filtering process in Daphnia, which is forced to clean its food groove 
(Burns, 1969; Gliwicz, 1980). This vulnerability to interference appears to be size-specific, with cladocerans of greater body size more severely affected (Gliwicz, 1977, 1990; Richman \& Dodson, 1983; Threlkeld, 1985). In Lake Breukeleveen only the small-sized $D$. cucullata increased in numbers after the manipulation (end of May 270 ind.1 $1^{-1}$, Fig. 3), but it declined again in mid June; its small clutch size indicate a bad food condition in the summer. The zooplankton grazing pressure in 1989 did not differ from the rates already known for this lake (Table 3, Gulati, 1984) except in end May when the rates were invariably high. Also the specific clearance rates (SCR: Table 3) support the idea that the lake has not changed since 1984. The concentration of filamentous cyanobacteria was already high $\left(100000 \mathrm{fil} \mathrm{ml}^{-1}\right)$ at the start of the manipulation in March 1989, probably due to the relative high temperatures in the proceding winter. These concentrations are higher than those ( $80000 \mathrm{fil} \mathrm{ml}^{-1}$ ) shown by Dawidowcz et al. (1988) to be critical for D. magna. Most probably the large-bodied Daphnia spp. were not able to establish due to the high concentration of filamentous cyanobacteria from the beginning of the manipulation onwards, while $D$. cucullata did not have such a disadvantage during the spring (Gliwicz, 1990). On the other hand, in Lake Zwemlust, the phytoplankton population consisted at the start of the food-web experiment of small colonies of Microcystis aeruginosa, which are readily ingested by large-bodied daphnids (Thompson et al., 1982). The difference in phytoplankton composition of both lakes perhaps influenced the outcome of the manipulation.

A third possible factor contributing to the ineffectiveness of the manipulation measures in Lake Breukeleveen is the inability of macrophytes to establish because of the low transparency of the lake due to resuspension of bottom material induced by wind. Thus, submerged macrophytes could not grow, spread and stabilize the ecosystem, like they did in Lake Zwemlust. Only near the shore and in the bays, where turbulence was less, the macrophytes were able to develop.

Concluding, in Lake Breukeleveen food-web manipulation by reducing the planktivorous fish population from $150 \mathrm{~kg} \mathrm{ha}^{-1}$ to $57 \mathrm{~kg} \mathrm{ha}^{-1} \mathrm{did}$ not cause an increase in water transparency nor a change in the lake's ecosystem from one dominated by cyanobacteria, rotifers and planktivorous fish to one characterized by submerged macrophytes and piscivorous fish. Application of additional measures is necessary to restore this lake, especially aimed at lowering the concentrations of cyanobacteria filaments to levels not inhibiting filtering mechanisms of large-bodied zooplankton. One may think of a further reduction of the $\mathbf{P}$ load to the lake and of applying coagulants to reduce suspended particles. Also the application of species specific-phytoplankton parasites, so as to increase phytoplankton mortality as demonstrated for diatoms (Van Donk \& Ringelberg, 1983) and cyanobacteria (Canter, 1972), may be useful in future. Resuspension of bottom material by wind can be reduced by dredging or building islands and dams. In 1990 in situ experiments will be carried out to study the effect of different combinations of measures.

\section{Acknowledgements}

We thank Piet Bakker, Jouke Kampen, Gerard Manshanden and their co-workers for carrying out the fishery operations, Bert Lanjouw, Paula Kniese, Guus Postema and Klaas Siewertsen for their work in the field and laboratory, and Mirjam Coops for typing the maniscript.

\section{References}

Best, E. P., D. De Vries \& A. Reins, 1984. The macrophytes in the Loosdrecht Lakes: A story of their decline in the course of eutrophication. Verh. Int. Ver. Limnol. 22: $868-875$.

Beukema, J. J. \& G. J. de Vos, 1974. Experimental tests of a basic assumption of the capture-recapture method in pond populations of carp, Cyprinus carpio L. Fish. Biol. 6: 317-329.

Buck, D. H. \& Ch. F. Thoits, 1965. An evaluation of Petersen estimation procedures employing seines in I-acre ponds. J. Wildlife Mgmt. 29: 598-621. 
Burger-Wiersma, T., M. Veenhuis, H. J. Korthals, C. C. M. Van Wiel \& L. R. Mur, 1986. A new prokaryote containing chlorphylls $a$ and $b$. Nature 320: 262-264.

Burns, C. W., 1968. Direct observations of mechanisms regulating feeding behavior of Daphnia in lake water. Int. Rev ges. Hydrobiol. 53: 83-100.

Canter, H. M., 1972. A guide to the fungi occurring on planktonic blue-green algae. In T. V. Diskachary (ed.), Proceedings of the Symposium on Taxonomy and Biology of Blue-green Algae. Univ. of Madras: 148-158.

Dawidowicz, P., Z. M. Gliwicz \& R. D. Gulati, 1988. Can Daphnia prevent a blue-green algal bloom in hypertrophic lakes? A laboratory test. Limnologica (Berlin) 19: 21-26.

De Kloet, W. A., P.J. Boesewinkel-de Bruijn \& B. Z. Salome, 1984. The phytoplankton and its production rates in the Loosdrecht lakes. Verh. Int. Ver. Limnol. 22: 848-852.

Edmondson, W. T. \& A. H. Litt, 1982. Daphnia in Lake Washington. Limnol. Oceanogr. 27: 272-293.

Frost, T. M., D. L. DeAngelis, S. M. Bartell, D. J. Hall \& S. H. Hurlbert, 1988. Scale in the design and interpretation of aquatic community research. In S. R. Carpenter (ed.), Complex interactions in lake communities. SpringerVerlag: 229-261.

Gliwicz Z. M., 1977. Food size selection and seasonal succession of filter feeding zooplankton in an eutrophic lake. Ekol. pol. 25: 179-225.

Gliwicz, Z. M., 1990. Why do cladocerans fail to control algal blooms? Hydrobiologia 200/201: 83-97.

Gliwicz, Z. M. \& J. Pijanowska, 1989. The role of predation in zooplankton succession. In U. Sommer (ed.): Plankton Ecology: Succession in planktonic communities. Springer, Heidelberg: 253-297.

Gliwicz.Z. M. 1990. Why do cladocerans fail to control algal blooms?' Hydrobiologia 200 201: 83-91.

Gliwicz, Z. M. \& J. Pijanowska, 1989. The role of predation in zooplankton succession. In U. Sommer (ed.): Plankton Ecology: Succession in planktonic communities. Springer, Heidelberg: 253-297.

Gons, H.J., 1987. The relationship between water transparancy and suspended particles in the Loosdrecht lakes, with regard to swimming water standards (in Dutch). Internal Report 1987-12; WQL Report, 61 p.

Gulati, R. D., 1984. The zooplankton and its grazing as measures of trophy in the Loosdrecht Lakes. Verh. Int. Ver. Limnol. 22: 863-868.

Gulati, R. D., 1989. Structure and feeding activity of zooplankton community in Lake Zwemlust, in the two years after biomanipulation. Hydrobiol. Bull. 23: 35-49.

Gulati, R. D., 1990. Zooplankton structure in the Loosdrecht lakes in relation to trophic status and recent restoration measures. Hydrobiologia 191: 173-188.
Kal, B. F. M., G. B. Engelen \& Th. E. Cappenberg, 1984. Loosdrecht lakes restoration project: Hydrology and physico-chemical characteristics of the lakes. Verh. int. Ver. Limnol. 22: 835-841.

Karabin, A., 1974. Studies on the predatory role of the cladoceran Leptodora kindtii (Focke) in secondary production of two lakes with different trophy. Ekol. Pol. 22: 295-310.

Leentvaar, P. \& M. F. Mörzer Bruijns, 1962. The population of the Loosdrecht lakes and its consequences. Levende Natuur 65: 42-48 (in Dutch).

Loogman, J. G. \& L. Van Liere (eds), 1986. Restoration of shallow lake ecosystems with emphasis on Loosdrecht Lakes. Hydrobiol. Bull. 20: 269.

Mordukhai-Boltovskaya, E. D., 1958. Preliminary notes on the feeding of the carnivorous cladocerans Leptodora kindtii and Bythotrepes. Dokl. Biol. Sci. Sect. 122: 828-830.

Richman, S. \& S. I. Dodson, 1983. The effect of food quality on feeding and respiration by Daphnia and Diaptomus. Limnol. Oceanogr. 28: 948-956.

Thompson, J. M., A. J. D. Ferguson \& C. S. Reynolds, 1982. Natural filtration rates of zooplankton in a closed system: the deriviation of a community grazing index. J. Plankton Res. 4: 545-560.

Threlkeld, S. T., 1985. Resource variation and the initiation of midsummer declines of cladoceran populations. Arch. Hydrobiol. Beih. Ergebn. Limnol. 21: 333-340.

Van Densen, W. L. T., C. Dijkers \& R. Veerman, 1986. The fish community of the Loosdrecht lakes and the perspective for biomanipulation. Hydrobiol. Bull. 20: 147-163.

Van Donk, E. \& J. Ringelberg, 1983. The effect of fungal parasitism on the succession of diatoms in Lake Maarssenveen (The Netherlands). Freshwat. Biol. 13: 241-251.

Van Donk, E., R. D. Gulati \& M. P. Grimm, 1989. Food-web manipulation in Lake Zwemlust: positive and negative effects during the first two years. Hydrobiol. Bull. 23: $19-35$.

Van Donk, E., M. P. Grimm, R. D. Gulati \& J. P. G. Klein Breteler, 1990. Whole-lake food-web manipulation as a means to study community interactions in a small ecosystem. Hydrobiologia 200/201: 275-289.

Van Liere, L., 1986. Loosdrecht lakes, origin, eutrophication, restoration and research programme. Hydrobiol. Bull. 20: 9-15.

Van Liere, L., R. D. Gulati, F. G. Wortelboer \& E. H. R. R. Lammens, 1990. Phosphorus dynamics following restoration measures in Loosdrecht lakes. Hydrobiologia 191: 89-96.

Van Liere, L., O. F. R. Van Tongeren, L. Breebaart \& W. Kats (in press). Trends in chlorophyll and total phosphorus in Loosdrecht lakes, the Netherlands. Verh. Int. Ver. Limnol. 24. 